\title{
The Development of the Central Business District (CBD) Based on Public-Private Partnership
}

\author{
M. Ikhsan Setiawan ${ }^{1}$, Agus Sukoco ${ }^{2}$, Iswachyu Dhaniarti ${ }^{3}$, Cholil Hasyim ${ }^{4}$ \\ ${ }^{123}$ Narotama University \\ ${ }^{4}$ UNDAR University Jombang \\ ikhsan.setiawan@narotama.ac.id,
}

Received : Juli 12, $2017 \quad$ Accepted : $\quad$ September 8, 2017

\begin{abstract}
This research aims to develop a model of the development of the Central Business District (CBD) based on Public-Private Partnership. Objective is (1) To design a development model Central Business District-based public-private partnership (public-private partnership) through case studies in Surabaya (Suramadu Surabaya side managed by Badan Pengembangan Wilayah Suramadu), (2) Develop a feasibility analysis of the technical-economical (feasibility study) the development of Business Central District-based public-private partnership (publicprivate partnership) in Surabaya (Suramadu Surabaya side) managed by the BadanPengembangan Wilayah Suramadu, by mapping, identification-evaluation of the obstacles encountered, opportunities and strategies and formulations can be developed. Lease (HGB) 30 year Rp. $500.000 / \mathrm{m}^{2} / \mathrm{yr}$; Sales $80 \%$; Sales price $/ \mathrm{m}^{2} \mathrm{Rp} .15,000,000 / \mathrm{m}^{2}$ (up $10 \% / \mathrm{yr}$ ); Management \& Rental Public Facility $5 \%$ of sales revenue. Based on the analysis of the feasibility of investment in the CBD area pessimistic conditions, showed decent results with NPV Rp. 7,152,755,613,547, IRR 14.34\%, 1.37 PI and PBP 17 years.
\end{abstract}

(c) 2017 Published By IJTI. This is an Open Acces article under the CC BY SA License https://creativecommons.org/licenses/by-sa/4.0/

Keyword : Central Business District (CBD), Public-Private Partnership, feasibility analysis

\section{INTRODUCTION}

Regional autonomy through UU No. 22/1999 and UU No. 34/2004 facilitate provincial, district and municipal innovations to generate income and global orientation. Economic development in the region is a joint collaboration between the central government, local government, state enterprises, enterprises, and private enterprises. Private parties will be given a major and important role in economic development, especially in the increased investment and job creation, while the government will act as regulator, facilitator and catalyst (KemenkoPerekonomian, 2011). The development of public and private cooperation model (Public-Private Partnership) to accelerate the expansion of the business center to the regions. PPP implementation in the region, referring to Pasal 195 of UU No. 34/2004 concerning the provision of public services, local governments may cooperate with third parties. PP No. 6/2006 on the management of state property / area stated that the State assets can be utilized by enterprises, in this case, including the state assets which business entities doing business under a concession granted, or the assets built by a business entity for the benefit of the Government and then operated by the Business Entity. The appointment of a business entity to leverage state assets should be done through a competitive bidding process. Forms of use of state property or areas in the form of rental, leasing, joint use, waking up to the transfer (BOT) and get up to deliver to (BTO). PP No. 50/2007 on Procedures for the Implementation of the Regional Cooperation stated that the cooperation between local governments and enterprises must be approved by the Legislative Council, where such cooperation resulted in the utilization of local government assets. The pattern of development of cooperation other 
business centers in the region is with the privatization, one of which enterprises PT Building Jaya AncolTbk (IDX, 2013). The owner of the company is the local government of DKI Jakarta $(72 \%)$, PT Building Jaya (18.01\%) and public (9.99\%). Managing the land area of 500 ha includes recreation zone (200 ha), industrial zones and the zone of the property, PT Building Jaya AncolTbk has made a significant contribution not only for the company but also for the government of Jakarta as the owner of the dominant shareholders in the form of deposit income (PAD area). Based on data from the Ministry of the Interior on the budget 2013, the contribution of non-tax revenue and levy provincial government of Jakarta Rp. 3,252 trillion. With total revenue of $\mathrm{Rp}$. 26670.45 trillion, the contribution of non-tax revenue and levy of $12.19 \%$, including the share of profit enterprises PT Building Jaya AncolTbk. Although local investment through foreign / domestic investment governed by UU No. 25/2007, but the government has not been optimal create a conducive business climate. Doing Business 2014, Indonesia at position 120 in terms of the ease of doing business, rising from position 128 in 2013, but lower than other ASEAN countries (Singapore 1st, Malaysia 6th, Thailand 18th, Brunei Darussalam 59th, 99th Vietnam and the Philippines to 108). The World Bank appreciated the ease in the business sector, particularly regarding the provision of credit to the real sector and tighten control of credit to the real sector in order to reduce the potential for non-performing loans (World Bank and IFC, 2013). Doing Business 2012 report showed improvement process by local government investment through ease in setting up a business, dealing with construction permits and registering property (World Bank \& IFC, 2012).Government assets in the area can be developed into a regional economic center, thereby increasing the value (value) of the property the area. Some local governments have run-private partnership scheme is however in the long-term implementation found some problems in the area of asset management, among others, related to the system of governance (good governance) and development (development). The low income local governments, weak local government's role in overseeing the property management area, the declining quality of public services is the domain of local governments and poor property maintenance area by the investor. It appeared among others in the management of the city of Medan Petisah Market (medan.tribunnews.com, 2013), Beringharjo city of Yogyakarta (www.jogjakota.go.id, 2013), Market Eggplant Makassar (www.fajar.co.id, 2013), Tanah Abang Market Block A provincial Jakarta (lipsus.kompas.com, 2013). On the other hand investors are demanding a return on investment and profit in accordance with the agreement and business plan. Infrastructure development of regional economy based on governmentprivate partnership is expected to increasingly dominant, with the financial condition of area 54.217 trillion deficit and the lack of budget revenue derived from the reception results separated areas of wealth management and other legitimate PAD (11.48\%) (Kemendagri, 2013), on the other hand the balance of the provincial governments and cities / regencies in Indonesia in 2010 showed assets of Rp 558.456 trillion land and building assets / buildings worth Rp 228.343 trillion (Kemendagri, 2010). Research infrastructure of regional economic development model based on public-private partnership (public-private partnership) is very original and very important in Indonesia, based on several reference journals / International conference. Beijing Tsinghua Univ Research Team and The Hong Kong Polytechnic Univ (Ke, 2009) conduct res earch related to the publication of research public-private partnership (public private partnership) through the search engine 1998-2008, with most publications derived from United Kingdom (UK) as much as 42 Institut / University, 82 researchers and 59 research teams published, whereas only 1 of the Indonesian Institute / University, one of the research team and first published research. This shows that the research related to public-private partnership (public private partnership) is still very low in Indonesia and is very important to be developed and published.Research and publications related to public-private partnership project (public private partnership) becomes an important one to see the data PT Sarana Multi Infrastruktur (Persero) has financed projects worth a total of Rp 35.6 trillion since 2009 with the PPP scheme. Besides Asia Public / Private Partnership Institute - APPPI in the Conference in Surabaya and Jakarta in 2013 to submit data there are five (5) countries in Asia

The Development of the Central Business District (CBD) based on Public-Private Partnership M. Ikhsan Setiawan, Agus Sukoco, Iswachyu Dhaniarti, Cholil Hasyim 
with the highest ranking of the implementation of PPP, namely China, India, In donesia, Vietnam and Malaysia. The emergence of Indonesia as one of the targets of implementation of PPP by APPPI increasingly shown the importance of research and publication of PPPs in Indonesia to support an increase in prosperity and welfare of the community in the area.

Local revenues are all revenues that come from the region itself as well as allocations from the central government as the right of local governments do not have to be repaid by the region. From 2008 to 2013, the local revenue grew by $75.3 \%$ from Rp. 365.1 trillion (in 2008) to Rp. Triliiun 640.2 (2013). But the budget year 2013 budget revenues were derived from non-taxes and charges are still very low (less than 10\%), thus improving the quality of absolute enhanced wealth management area (MoF, 2013). Todaro (Todaro, 1997) stated that there are three major factors or components that influence the economic growth of the region, three are capital accumulation, population growth and technological progress. People's lives have been very dependent on services provided by the government, many people who benefit from the activity and government spending, some research results show the positive role of public capital on economic growth (Aschauer, 1989). Ida BagusRaka Surya Atmaja (Atmaja, 2001) analyzed the effect of private investment, public sector investments include government investment, government consumption, government revenue from taxes / non tax as well as the population growth of the level of economic growth counties and cities in Bali. The results showed that private investment plays a very dominant in Bali, seen from its significance exceeds government investment. AdiRaharjo (Raharjo, 2006) analyze the effect of private investment to the economic growth of Semarang show positive results, a significant and real impact on regional economic growth. Negoro (Negoro, 2006) states that the revitalization of the market can relive the important role of traditional markets in the economic sectors of society by exploring the potential possessed in order to have high competitiveness of the existing competition (especially against the modern market), the revitalization of this market is to cooperate with the private sector using PPP cooperation pattern. Djunaedi (Djunaedi 2007) added that the PPP concept widely adopted by governments in order to encourage domestic and foreign private investors to cooperate in the provision of infrastructure, but in the process of PPP activities seem similar to the process of government procurement (Presidential Decree No.80 / 2003), According to the European Commission (2003) benefits by holding the PPP is the creation of community participation, improve the effectiveness of the private sector with the government procurement of public facilities, technology transfer, increasing accountability and minimizing risk by allocating to the parties most competent to handle it.

\section{MATERI AL AND METHOD}

The method used in this study as follows:

1) The case study approach refers to a method that emphasises qualitative analysis (Yin, 2009)

2) Research approach using qualitative research approaches (Denzin and Lincoln in LexyMoleong, 2005)

3) The research location in Surabaya (Suramadu Area Management Board), the site was taken in consideration in the area very attractive investor, has a high potential for local revenue and representing Eastern Indonesia.

4) Primary data, i.e. data obtained from the direct or first hand, especially regarding technical feasibility-economical (feasibility study), master plan and strategic plan for the development of infrastructure of regional economy based on public-private partnership (public-private partnership)

5) Secondary data can be online-offline information, reports, results of previous studies as well as other publications.

6) The interview was conducted in-depth interviews, the method of collecting data

The Development of the Central Business District (CBD) based on Public-Private Partnership M. Ikhsan Setiawan, Agus Sukoco, Iswachyu Dhaniarti, Cholil Hasyim 


\section{RESULT AND DISCUSSION}
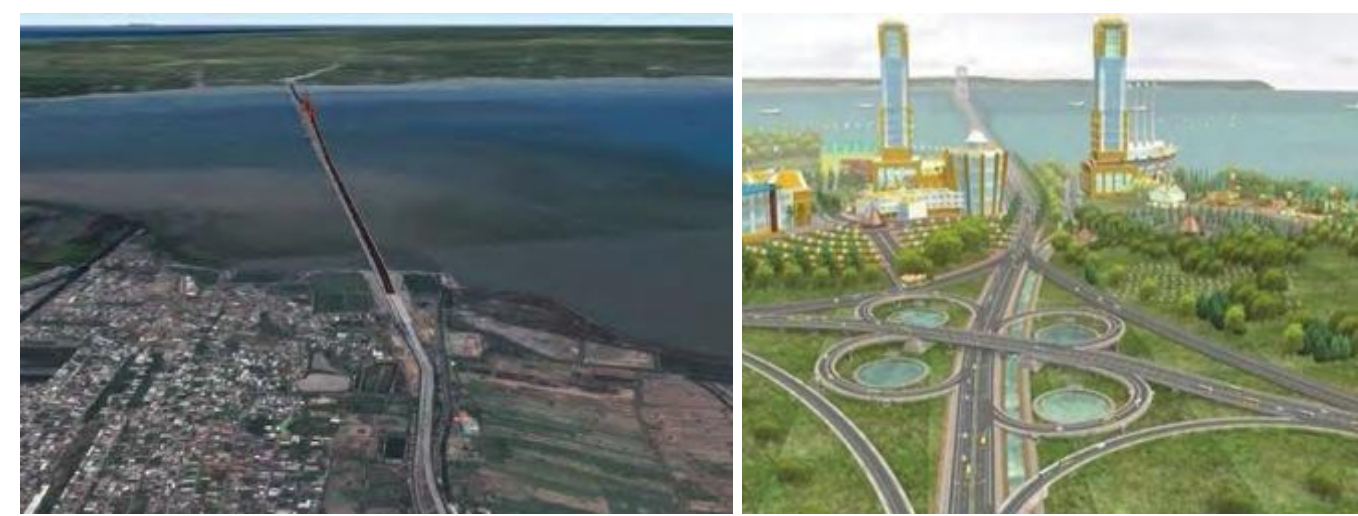

Figure 1. Existing and Planning of Suramadu (Surabaya Side Area) source: BPWS, 2011

The cost of land acquisition by the government. Investors through PPP did land rental / HGB to the government for 30 years. Lease payments are assumed to be conducted every 10 years. CBD land acquisition planned for 2014 and 2015. While the construction of the CBD area is divided into four stages of development, namely 2015, 2017, 2019 da 2025. Thus, the price of land and building of data adjusted for the time value of money for the year. Land (Rent / HGB 30 years), Discount / compound Factor (10\%), Source of Funds $(60 \%$ private by PPP), Interest Rate Loan (12\% / year), taxes $(25 \%)$, Operating Expenses (10\% of reception), Construction fee (1\% of investment costs)

\begin{tabular}{|c|c|c|c|c|c|c|}
\hline TAHUN & EAT & Penyusutan & Cash Inflow & DF $10 \%$ & $\mathrm{PVCl}$ & PBP \\
\hline 2014 & $(3.042 .391 .950 .000)$ & (1) & (3.042.391.950.000) & 1,000 & $(3.042 .391 .950 .000)$ & $(3.042 .391 .950 .000)$ \\
\hline 2015 & (1.994.846.582.839) & & (1.994.846.582.839) & 0,909 & $(1.813 .496 .893 .490)$ & $(4.855 .888 .843 .490)$ \\
\hline 2016 & 2.569 .094 .647 .153 & 369.354 .500 .000 & 2.938 .449 .147 .153 & 0,826 & 2.428 .470 .369 .548 & $(2.427 .418 .473 .942)$ \\
\hline 2017 & 3.165 .690 .500 .521 & 369.354 .500 .000 & 3.535 .045 .000 .521 & 0,751 & 2.655 .931 .630 .745 & 228.513 .156 .803 \\
\hline 2018 & 5.838 .421 .169 .585 & 716.953 .100 .000 & 6.555 .374 .269 .585 & 0,683 & 4.477 .408 .831 .080 & 4.705 .921 .987 .883 \\
\hline 2019 & 2.007 .357 .703 .193 & 716.953 .100 .000 & 2.724 .310 .803 .193 & 0,621 & 1.691 .582 .668 .343 & 6.397 .504 .656 .226 \\
\hline 2020 & 3.266 .155 .617 .561 & 901.065 .704 .500 & 4.167 .221 .322 .061 & 0,564 & 2.352 .287 .797 .067 & 8.749 .792 .453 .293 \\
\hline 2021 & 3.947 .553 .326 .226 & 901.065 .704 .500 & 4.848 .619 .030 .726 & 0,513 & 2.488.108.217.825 & 11.237 .900 .671 .118 \\
\hline 2022 & 238.995 .264 .504 & 901.065 .704 .500 & 1.140 .060 .969 .004 & 0,467 & 531.846 .855 .929 & 11.769 .747 .527 .048 \\
\hline 2023 & 405.267 .412 .351 & 901.065 .704 .500 & 1.306 .333 .116 .851 & 0,424 & 554.012 .763 .657 & 12.323 .760 .290 .705 \\
\hline 2024 & $(2.257 .290 .828 .202)$ & 901.065 .704 .500 & (1.356.225.123.702) & 0,386 & (522.883.495.399) & 11.800 .876 .795 .306 \\
\hline 2025 & 789.165 .113 .247 & 901.065 .704 .500 & 1.690 .230 .817 .747 & 0,350 & 592.415 .590 .336 & 12.393 .292 .385 .642 \\
\hline 2026 & 3.684.858.569.195 & 1.661 .689 .938 .000 & 5.346.548.507.195 & 0,319 & 1.703 .575 .122 .776 & 14.096 .867 .508 .417 \\
\hline 2027 & 2.610 .925 .703 .379 & 1.661 .689 .938 .000 & 4.272 .615 .641 .379 & 0,290 & 1.237 .624 .559 .613 & 15.334 .492 .068 .031 \\
\hline 2028 & 3.156 .372 .589 .022 & 1.661 .689 .938 .000 & 4.818 .062 .527 .022 & 0,263 & 1.268 .746 .448 .566 & 16.603 .238 .516 .596 \\
\hline 2029 & 3.756 .364 .163 .230 & 1.661 .689 .938 .000 & 5.418 .054 .101 .230 & 0,239 & 1.297 .039 .074 .886 & 17.900 .277 .591 .483 \\
\hline 2030 & 4.416 .354 .894 .858 & 1.661 .689 .938 .000 & 6.078 .044 .832 .858 & 0,218 & 1.322 .759 .644 .269 & 19.223 .037 .235 .751 \\
\hline 2031 & 5.142.344.699.649 & 1.661 .689 .938 .000 & 6.804 .034 .637 .649 & 0,198 & 1.346.141.980.071 & 20.569 .179 .215 .822 \\
\hline 2032 & 5.940 .933 .484 .919 & 1.661 .689 .938 .000 & 7.602 .623 .422 .919 & 0,180 & 1.367.398.648.982 & 21.936 .577 .864 .804 \\
\hline 2033 & 6.819 .381 .148 .716 & 1.661 .689 .938 .000 & 8.481 .071 .086 .716 & 0,164 & 1.386 .722 .893 .446 & 23.323 .300 .758 .250 \\
\hline 2034 & $(2.261 .076 .699 .469)$ & 1.661 .689 .938 .000 & (599.386.761.469) & 0,149 & $(89.095 .022 .814)$ & 23.234.205.735.436 \\
\hline 2035 & 2.080 .621 .375 .027 & 1.661 .689 .938 .000 & 3.742 .311 .313 .027 & 0,135 & 505.700 .664 .331 & 23.739.906.399.767 \\
\hline 2036 & 2.357 .637 .250 .027 & 1.292 .335 .438 .000 & 3.649 .972 .688 .027 & 0,123 & 448.384 .448 .378 & 24.188 .290 .848 .145 \\
\hline 2037 & 2.357 .637 .250 .027 & 1.292 .335 .438 .000 & 3.649 .972 .688 .027 & 0,112 & 407.622 .225 .798 & 24.595 .913 .073 .943 \\
\hline 2038 & 2.618 .336 .200 .027 & 944.736 .838 .000 & 3.563.073.038.027 & 0,102 & 361.743 .120 .885 & 24.957 .656 .194 .828 \\
\hline 2039 & 2.618 .336 .200 .027 & 944.736 .838 .000 & 3.563 .073 .038 .027 & 0,092 & 328.857 .382 .623 & 25.286 .513 .577 .450 \\
\hline 2040 & 2.756 .420 .653 .402 & 760.624 .233 .500 & 3.517 .044 .886 .902 & 0,084 & 295.099 .244 .064 & 25.581 .612 .821 .514 \\
\hline 2041 & 2.756 .420 .653 .402 & 760.624 .233 .500 & 3.517 .044 .886 .902 & 0,076 & 268.272 .040 .058 & 25.849 .884 .861 .572 \\
\hline 2042 & 2.756 .420 .653 .402 & 760.624 .233 .500 & 3.517 .044 .886 .902 & 0,069 & 243.883 .672 .780 & 26.093 .768 .534 .352 \\
\hline 2043 & 2.756 .420 .653 .402 & 760.624 .233 .500 & 3.517 .044 .886 .902 & 0,063 & 221.712 .429 .800 & 26.315 .480 .964 .152 \\
\hline 2044 & 2.756 .420 .653 .402 & 760.624 .233 .500 & 3.517 .044 .886 .902 & 0,057 & 201.556 .754 .364 & 26.517 .037 .718 .515 \\
\hline 2045 & 2.756 .420 .653 .402 & 760.624 .233 .500 & 3.517 .044 .886 .902 & 0,052 & 183.233 .413 .058 & 26.700 .271 .131 .573 \\
\hline \multicolumn{6}{|c|}{ TOTAL PVCI } & 26.700 .271 .131 .573 \\
\hline \multicolumn{6}{|c|}{ TOTAL PVIO } & 19.547 .515 .518 .026 \\
\hline \multicolumn{6}{|l|}{ NPV } & 7.152 .755 .613 .547 \\
\hline \multicolumn{6}{|l|}{ IRR } & $14,34 \%$ \\
\hline \multirow{2}{*}{\multicolumn{6}{|c|}{$\mathrm{PI}$}} & 1,370 \\
\hline & & & & & & 17 TAHUN \\
\hline
\end{tabular}

The Development of the Central Business District (CBD) based on Public-Private Partnership M. Ikhsan Setiawan, Agus Sukoco, Iswachyu Dhaniarti, Cholil Hasyim 


\section{CONCLUSIONS AND SUGGESTION}

Lease (HGB) 30 year Rp. $500.000 / \mathrm{m}^{2} / \mathrm{yr}$; Sales $80 \%$; Sales price $/ \mathrm{m}^{2} \mathrm{Rp} .15,000,000 / \mathrm{m}^{2}$ (up 10\%/yr); Management \& Rental Public Facility $5 \%$ of sales revenue. Based on the analysis of the feasibility of investment in the CBD area pessimistic conditions, showed decent results with NPV Rp. 7,152,755,613,547, IRR 14.34\%, 1.37 PI and PBP 17 years.

\section{REFERENCES}

Aschauer, David A, 1989, Back of the G-7 pack: public investment and productivity growth in the Group of Seven, Working Paper Series, Macroeconomic Issues 89-13, Federal Reserve Bank of Chicago

Atmaja, IBR Surya, 2001, PerananInvestasiSwasta, InvestasiSektorpublikdanPertumbuhanPendudukTerhadapPertumbuhan GDP di Indonesia, JurnalEkonomidanBisnis Indonesia, Vol 15, No.2

BadanKoordinasiPenanaman Modal, 2014, RealisasiPenanaman Modal PMDN-PMA Q4-2013, Jakarta, bkpm.go.id

Bank Dunia\& IFC, 2012, Doing Business di Indonesia: membandingkankebijakanusaha di 20 kotadan 183 perekonomian, The World Bank, Washington DC USA

Bank Dunia\& IFC, 2013, Doing Business 2014: Understanding Regulations for Small and Medium-Size Enterprises, The World Bank, Washington DC USA

Bank Indonesia, 2013, PerkembanganPropertiKomersial-Triwulan IV 2013, Jakarta, bi.go.id

Bursa Efek Indonesia, 2014, IDX Statistics 2013, BEI Research Divisions, idx.co.id

Bursa Efek Indonesia, 2014, Performance Summary PT Pembangunan Jaya AncolTbk, idx.co.id

DirjenKeuangan Daerah Kemendagri, 2010, Neraca APBD 2010, KementerianDalamNegeri RI, Jakarta

DirjenKeuangan Daerah Kemendagri, 2013, Postur APBD TahunAnggaran 2013, KementerianDalam Negeri RI, Jakarta

Djunaedi, Parptono, 2007, Implementasi Public-Private Partnerships danDampaknyake APBN, Majalah Warta Anggaran edisi-6, KementerianKeuanganDirektoratJendralAnggaran, Jakarta

European Commission, 2003, Guidelines for Successful Public-private Partnerships, Brussels Gulo, W, 2003, MetodologiPenelitian, Jakarta, PT GramediaWidiasarana Indonesia

Ke, Yingjian, et.al, 2009, Research Trend of Public-Private Partnership in Construction Journals, Journal of Construction Engineering \& Management ASCE, USA

KemeterianKoordinatorbidangPerek onomian, 2011, KerjasamaPemerintahdanSwasta: PanduanBagi Investor dalam Investasi di bidangInfrastruktur, Jakarta Marzuki, 2002, MetodologiRiset, Yogyakarta, BPFE-UII

Moleong, Lexy J, 2005, MetodologiPenelitianKualitatif, Bandung, PT RemajaRosdakarya

Negoro, Nugroho P, 2006, AnalisalndikatorPentingDalam Proses RevitalisasiPasarTradisionaldenganPendekatan Analytical Hierarchy Process (AHP), Jurnal Nasional Dikti, Jakarta

Petterson P.P, , 2002, Capital Budgeting: Theory and Practice, John Willey and Sons Inc.

PP no.50 tahun 2007 tentang Tata Cara PelaksanaanKerjasama Daerah

PP no. 6 tahun 2006 tentangPengelolaanBarangMilik Negara/Daerah

Rastogi, Tamboto, et.al, 2013, Asia's Next Big Opportunity: Indonesia's Rising Middle-Class and Affluent Consumers, The Boston Consulting Group, bcg.com

Santosa, Jatmiko, 2013, Public Private Partnership in Indonesia \& ASEAN-East Java Case Study, PT Sarana Multi Infrastruktur (Persero), Jakarta 
Shen, L.Y., et.al, 2007, Using bargaining-game theory for negotiating concession period for BOT-type contract, Journal of Construction Engineering and Management, Vol. 133, No. 5

Sirtaine S, et.al, 2005, How profitable are private infrastructure concessions in Latin America? Empirical evidence and regulatory implications, The Quarterly Review of Economics and Finance, Vol. 45

Tiffin R, 1999, Practical Techniques for Effective Project Investment Appraisal, Hawksmere PLC

Todaro, M.P. 1997. Pembangunan Ekonomi di DuniaKetiga, Ghalia, Jakarta

TOYO University-A3PI, Public-Private Partnership Conference, In Association with IIUM, ITB, and ITS, Bandung \& Surabaya, Indonesia, November 25-27, 2013

UU no.22 Tahun 1999 \& UU no. 34 tahun 2004 tentang Otonomi Daerah

Yin, R.K, 2009, Case study research. Design and methods, 4. Ed, Thousand Oaks, California.

Zhang, X, 2005, Critical Success Factors For Public-Private Partnerships In Infrastructure 